\title{
The Sensitivity and Specificity of a new Scoring System Using High Resolution Computed Tomography to Diagnose Lung Cancer
}

\author{
Arman A. Abdullah, ${ }^{1}$ Nurlela Bujang, ${ }^{1}$ Cholid Badril, ${ }^{1}$ Chairil Hamdani, ${ }^{2}$ Purnawan Junadi, ${ }^{3}$ Anwar Jusuf, ${ }^{4}$ Sarwono Waspadji ${ }^{5}$ \\ ${ }^{1}$ Department of Radiology, Medical Faculty, University of Indonesia \\ ${ }^{2}$ Department of Anatomic Pathology, Medical Faculty, University of Indonesia \\ ${ }^{3}$ Faculty of Public Health, University of Indonesia \\ ${ }^{4}$ Department of Pulmonology, Medical Faculty, University of Indonesia \\ ${ }^{5}$ Department of Internal medicine, Medical faculty, University of Indonesia
}

\begin{abstract}
Abstrak
Tujuan Mendapatkan metode diagnostik kanker paru dengan cara tidak invasif dengan HRCT sistem skoring yang setara dengan pemeriksaa Patologi Anatomik.

Metode Penelitian dilakukan dari Desember 2006 sampai dengan Maret 2008. Sebanyak 55 pasien, 40 laki-laki dan 15 perempuan yang diduga kanker paru diperiksa dengan CT-scan toraks teknik HRCT tanpa dan dengan kontras, dilanjutkan TTB dengan tuntunan CT untuk mendapatkan bahan sitologi.

Hasil Pemeriksaan PA didapatkan 43 pasien (78\%) kanker paru dan 12 pasien (22\%) tidak terbukti ganas/jinak. Berdasarkan kecocokan gambaran HRCT dan PA dibuat skor untuk umur > 49 tahun, volume tumor lebih dari 68 cm3, HU lebih dari 21, spikula positif, dan angiogram + serta $K G B+$, dengan nilai masing-masing 20, 19, 10, 24, 18, dan 17 skor total 108.

Kesimpulan Tehnik baru dalam mendiagnosis kanker paru dengan HRCT sistem skoring setara dengan pemeriksaan patologi anatomik dengan sensitivitas $97,7 \%$ dan spesifisitas $83,3 \%$ dengan nilai batas skor 35 . Bila skor $<35$ berarti lesi jinak dan bila skor >35 berarti ganas (Med J Indones 2009;18:181-8)
\end{abstract}

\begin{abstract}
Aim To find a non-invasive diagnostic method for lung cancer with the results almost as accurate as histopathological examinations using HRCT scoring system.

Method This study was conducted from December 2006 until March 2008. A total of 55 persons, comprised of 40 male and 15 female patients suspected of having lung cancer, underwent high resolution computed tomography with and without contrast as well as CT-guided transthoracic needle aspiration to obtain cytology specimens.

Results Histopathological examinations revealed the existence of lung cancer in 43 patients (78\%) and benign lesions in 12 patients $(22 \%)$. A scoring system was then made based on the similarities of findings from CT and histopathologic examinations. In the the age group of 49 years and above, tumor volume of more than $68 \mathrm{~cm} 3$, HU of more than 21 , spicula positive, angiogram positive and lymph node positive had a value of respectively $20,19,10,24,18$, and 17 (total score 108).

Conclusion This new method to diagnose lung cancer is constantly as accurate as histological findings with a sensitivity of $97.7 \%$ and a specificity of $83,3 \%$ and a cut-off score of 35 . According to this system, a score of less than 35 indicates that the lesions were benign while a score higher than 35 is suggestive malignant.(Med J Indones 2009;18:181-8)
\end{abstract}

Key word: High resolution CT; Lung cancer; Scoring

Lung cancer that originated from bronchial epithelium. This disease is one of the most common causes of death among malignancies throughout the world. ${ }^{1,2}$ In the United States, lung cancer is the second most common cause of death in male and the third most common cause of death in female. In 2003 there were 157.200 death cases caused by lung cancer and 171.900 new cases were found, increased to 173.770 new cases the next year. ${ }^{3}$ In Japan, lung cancer is the most common cause of death in male and is the second most common cause of death in female. This is due to increasing number of smokers among women.

In general, lung cancer manifests in persons above 40 and mostly in those 60-70 years of age. This disease is seldom found in those below 35 years of age. The ratio of lung cancer found in male and female is $1.4: 1.3,4$ In Indonesia lung cancer ranks the fourth among the most common cancers after breast, cervical and nasopharyngeal cancer. The ratio between male and female patients is $4: 1 .^{5}$ 
Lung cancer is the fourth most commonly occuring cancers in Indonesia after breast, cervical and nasopharyngeal cancers. Diagnosis of lung cancer is confirmed by histopathological findings from specimens collected from biopsy. Unfortunately, biopsy is not always possible for very small tumors or tumors located in unreacheable areas. In other cases, patients may be too severely ill or refuse the invasive procedures like bronchoscopy, biopsy or surgery. On the other hand, a high resolution chest CT technique can accurately reveal the morphology and anatomy of lung abnormalities.

Lung cancer has become a major health problem in Indonesia. It has been a challenge to manage because it is often misdiagnosed as tuberculosis, thus delaying referral and proper treatment. This explains why most patients come at a late stage. The incidence of cancer in Indonesia is estimated to be 100 per 100.000 population. There is no accurate data for lung cancer, although there are probably 800-1000 new cases per year. More than $90 \%$ of the new cases of lung cancer come for medical treatment at a late stage. In Persahabatan Hospital only $6 \%$ of all the cases are still operable. ${ }^{4}$

The diagnosis of lung cancer requires pathological confirmation (histology or cytology). Many cases cannot be confirmed due to very small tumor size, difficulty to reach the location of the tumor, severely ill patients and refusal from the patients to undergo invasive procedures such as bronchoscopy, biopsy or surgery. In Persahabatan Hospital, the national referral hospital for lung disease, $20 \%$ of lung cancer patients were not treated appropriately due to negative histological diagnosis. Most probably, in peripheral hospitals, where the facilities are not sufficient, more than $50 \%$ of patients suspected of lung cancer were not treated as lung cancer patients.

An alternative method to diagnose lung cancer accurately is urgently required in cases where histopatological examinations cannot be performed. A chest CT with HRCT technique can predict this malignancy. ${ }^{6,7}$ The aim of this study is to develop an HRCT scoring system, that can predict lung cancer as accurately as histopathological analysis.

\section{METHOD}

We performed a cross sectional study on 55 patients aged 23-80 years, comprised of 40 male and 15 female patients suspected of having lung cancer. Patients underwent HRCT with and without contrast and CTguided Trans Thoracic Needle Aspiration (TTNA) to obtain cytological specimens at Cipto Mangunkusumo General Hospital, Jakarta from December 2006-March 2008. All cytological specimens were then analyzed in the Departement of Pathological Anatomy, Faculty of Medicine, University of Indonesia.

The items evaluated from the CTfilms were volume of the tumor, HU, spicula, ground glass opacity, calcification, pleural tail, Rigler notch sign, angiogram sign, cavity, atelectasis, infiltrate, bone destruction, pleural fluid, metastasis and the enlargement of the lymph node. Other diagnostic methods for lung cancer included histological samplings of sputum, bronchoscopy, pleural puncture and lymph node biopsy, and were performed by attending pulmonologists.

\section{Procedure}

The CT machine used was Somatom Sensation 4 made by Siemens which can perform the HRCT technique specifically for Lung CT Scan with or without contrast with $120 \mathrm{KV}$ and $90 \mathrm{MAS}$. The crossing line was made from the 6 th to 7 th cervical vertebra passing the adrenal gland until the middle pole of the right kidney with lung window settings Wd 1200, W1, -500 and mediastinal window $\mathrm{Wd} 400$ and $\mathrm{W} 140$. The contrast used was from the non-ionic group (Iopamiro 300), given as an intravenous bulk injection with 2,5 cc/second, 1-1,5 $\mathrm{ml} / \mathrm{kg}$ body weight $(80-100 \mathrm{cc})$ mixed with $10-20 \mathrm{cc}$ of sterile water, with pressure $250 \mathrm{psi}$ and delayed scan 30 seconds after contrast injection. 8 The CT-guided Transthoracic Biopsy (TTB) was done in all patients to obtain cytological specimens that were then sent to the Departement of Pathological Anatomy, Faculty of Medicine, University of Indonesia for analysis. In the main abnormality group special measurement in this research is volume, different from previous literature where measurement was based on the biggest diameter on one side only. Volume of the tumor mass was measured manually, because the HRCT multislice 4 device could not automatically measure the volume. HU attenuation was determined before and after contrast administration at the most dense area. The HU difference was counted before and after contrast administration in the same location. ${ }^{9}$

Data of volume and HU in the continuous form was made categorical for practical reasons, with Receiver -Operating-Characteristic (ROC) analysis. The crossing point was determined by considering optimal sensitivity and specificity. 
Other diagnostic tests such as bronchoscopy, biopsy, bronchial lavage, bronchial brushing or needle aspiration of bronchial mass or intrathoracic tumor or Trans Bronchial Lung Aspiration (TBLB) were performed. All cytological or histological specimens were analyzed at the Departement of Pathological Anatomy, Faculty of Medicine, University of Indonesia.

\section{Operational Definition}

There are two major groups of abnormalities found in CT imaging which were evaluated in this study, i.e. main abnormalities which consisted of ten items and additional abnormalities which have eight items. The entire ten items of the main abnormalities are described as the following: tumor volume was measured three-dimensionally depending on the tumor shape, unfortunately the scanner that we had could not calculate the volume automatically, hence they were calculated manually from three different dimension. Second item is tumor's location that is the position in the lung (peripheral, central, or mediastinal). Then third item, the tumor's shape was divided into two types; lobulated or polygonal. Afterwards, a spicula defined as a fibrous tissue causing retraction on tumor's wall that extends to adjacent lung parenchyma was noticed as well.

Fifth item is density measurement (Houndsfield unit/ $\mathrm{HU}$ ) of an object in CT imaging. Each body organ or matter has different HU value. For instance, air has the HU value of minus 1000 , bone has positive 1000 , while liquid has density of minus 25 and solid soft tissue $>$ 35 . In this study, HU values were calculated twice, before and after contrast administration in the same location. Sixth item is ground glass opacity defined as a consolidated image of a small size tumor $(<2 \mathrm{~cm})$ with air-bronchogram within the tumor. Then, seventh item is calcification defined as increased attenuation inside the tumor, which has the density between 100-200 HU and has the shape of punctate, reticular, amorphic, or diffused. Generally, a diffused calcification image is likely to be benign, but if the location is irregular and the tumor size is $>3 \mathrm{~cm}$, the lesion is likely to be malignant. Eighth item is a pleural tail defined as fibrotic stripes that connect the tumor to the visceral pleura, defined as desmoplastic reaction on a peripheral tumor's septa. Ninth item is a Rigler notch sign defined as the image of lung arterial vessels which supply the tumor. In the CT imaging, it appears as a notch in the tumor. The last item is an angiogram sign defined as the the image of blood vessels in the tumor resembling linear stripes caused by intravenous contrast administration. The appearance of the linear stripes meant that tumor vascularization was prominent and had the tendency to be malignant.
After main abnormalities evaluation, additional lesion which consisted of eight items are described as the following: first item was infiltrates defined as mottled images that surround the tumor, it was also a sign of infection caused by airway obstruction by the tumor. This mottled spot would be clearly seen in the lung window and would not be seen in the mediastinum window. Second item is cavity defined as a small abscess image with a thick wall margin of more than $1.5 \mathrm{~mm}$. Third item of additional abnormalities is atelectasis defined as collapse of lung parenchyma distal from a tumor due to obstruction, or depression, or lymph nodes enlargement of the bronchial branch by a tumor. Next item is lymph nodes of which diameters less than $5 \mathrm{~mm}$ considered normal. Infection or malignant tumors may cause lymph nodes to enlarge growing to be more than $10 \mathrm{~mm}$ in diameter and would be clearly seen the CT imaging in the mediastinum window.

Infiltration is defined as the invasion of a tumor to adjacent tissue, such as the superior superior vena cava, pericardium, aorta, trachea, and esophagus. Infiltration of the tumor to the superior vena cava may cause superior vena cava syndrome. In HRCT, it would be observed as a tumor mass infiltrating the superior vena cava (SVC) resulting in the narrowing of the SVC lumen. Pleural effusion defined as abnormal presence of liquid the pleural cavity which would be observable if the volume reached $>100 \mathrm{cc}$. Pleural effusion may indicate extensive infiltration of the pleura.

Next item is bone destruction defined as the pathological bone loss which involves the ribs, sternum, or thoracic vertebra as part of the chest wall structures. The destruction can be caused by direct tumor infiltration to adjacent bones or through hematogenous metastatic spreading. Bone damage would be clearly observable in the bone window in HRCT.

Metastasis is defined as the hematogenous tumor extension observable as multiple nodules in the lung. By HRCT, the lesion would be observable if it was at least $1-2 \mathrm{~mm}$ in diameter, while in conventional $\mathrm{CT}$ it has to be at least $5 \mathrm{~mm}$. Nodules may be seen ipsilaterally or contralaterally. The adrenal gland enlargement would be categorized as one of the sign of metastasis, so scanning should cover the middle pole of the right kidney as the lower margin.

The definite diagnosis of malignant tumor was determined if cytologic and histopathologic findings showed malignant cells or tissue. If malignant cells/tissue were not found, or histologic/cytologic findings showed other abnormalities, the diagnosis is considered as benign. 


\section{Data Analysis}

Univariate, bivariate, and multivariate tables were analyzed with diagnostic test $2 \times 2$ table, comparing HRCT examination to the histopahological results. A statistic software was used to determine sensitivity, specificity, positive predictive value, and negative predictive value. The last stage was to calculate the scores in order to compare HRCT imaging of main abnormalities and additional lesions to histopathological results, and also by inserting demographic characteristic (age). Bivariate and multivariate calculations were done using STATA to establish variables with certain values. Variables $p \leq 0.25$ were included in the scoring system. The scores were achieved from the calculation of coefficient divided by standard error coefficient of each variable. The variable with the lowest value was used as reference to determine the index of comparative results, dividing each variable value by standard value as basic reference. After score value was accomplished, a cut-off point was determined to discern the boundary between benign and malignant. Total score was determined from the entire calculation of each variable.

\section{RESULTS}

In 43 patients, malignant cells were found, adenocarcinoma was identified in 13 patients, squamous cell carcinoma in 8 patients, and only 2 cases of small cell carcinomas. No large cell carcinomas were identified in this study.

There were 16 patients with non-small cell lung carcinomas. This tumor cannot be categorized into adenocarcinomas, large cell carcinomas or squamous cell carcinomas, since the cytological results were not specific.

In 12 patients, malignant cell were not found, however this did not rule out the possibility of malignancy. There were 7 cases in which the origins of the tumor could not be determined, and only 4 patients with tuberculosis and 1 unidentifiable teratoma. Patients with tuberculosis and teratoma could not be excluded from this study since in the chest $\mathrm{x}$-ray the nodules were suspected as lung cancer. Tuberculosis and teratoma (benign) were identified only through pathology. (Table 1)

In this study the results of HRCT in 11 patients were benign and 10 patients $(90.9 \%)$ were in accordance with the pathological results as benign lesion (malignant cells not found), but only 1 patient showed malignant cells. Whereas in the other 44 patients HRCT showed malignancy. There was concordance between pathology and HRCT in 42 patients (95.5\%) and only 2 patients showed benign results (Table 2).
Table 1. Results of Pathological Anatomy

\begin{tabular}{lcc}
\hline Characteristics & Malignant & Benign \\
\hline NSCLC & 16 & 0 \\
Adenocarcinoma & 13 & 0 \\
Squamous cell carcinoma & 8 & 0 \\
Small cell carcinoma & 2 & 0 \\
Thymoma & 4 & 0 \\
Malignant cells not found & 0 & 7 \\
Tuberculosis & 0 & 4 \\
Teratoma & 0 & 1 \\
\hline Total & 43 & 12 \\
\hline
\end{tabular}

Table 2. Comparison of PA and HRCT results

\begin{tabular}{lccc}
\hline & \multicolumn{2}{c}{ Total } \\
\hline Malignant & Malignant & Benign & \\
Benign & 42 & 2 & 44 \\
Total & 1 & 10 & 11 \\
\hline
\end{tabular}

Comparisons of HRCT and pathological results showed that the HRCT method had the sensitivity of $97.7 \%$, specificity of $83.3 \%$, positive predictive value of $95.5 \%$ and negative predictive value of $83.3 \%$. This means that HRCT can detect $95.57 \%$ of all malignant tumors and $90.9 \%$ of all benign lesions.

\section{Scoring}

We performed a multivariate analysis resulting in 6 important variables to predict lung cancer, categorized as main abnormalities, additional abormalities and demographic characteristics (Table 3).

Table 3. Lung cancer prediction model with $p$ value

\begin{tabular}{lcclcl}
\hline Variable & Coef & SE Coef & OR & $(95 \%$ CIOR $)$ & p value \\
\hline Age & 5,76 & 2,95 & 316,7 & $(1,0-1036,7)$ & 0,051 \\
Volume & 4,36 & 2,34 & 78,3 & $(0,8-7651,5)$ & 0,062 \\
Angiogram & 6,77 & 3,92 & 870,8 & $(0,4-1876,0)$ & 0,084 \\
Spicula & 3,93 & 1,68 & 50,7 & $(1,9-1366,9)$ & 0,019 \\
Lymph node & 4,05 & 2,46 & 57,1 & $(0,5-7123,0)$ & 0,100 \\
HU $>21$ & 1,76 & 1,80 & 5,8 & $(0,2-1990,6)$ & 0,228 \\
Constant & $-8,77$ & 4,10 & & & 0,033
\end{tabular}

A scoring system was establish using findings from HRCT, chest CT and anatomical pathology as well as demographic data, where by the age group of 49 years and above, tumor volume of more than $68 \mathrm{~cm} 3$, HU of more than 21 , spicula + , angiogram + and enlargment of the lymp nodes + have a value of respectively 20, 19, 10, 24, 18 and 17 total score 108 (Table 4) 
Table 4. Scoring to predict lung cancer

\begin{tabular}{|c|c|c|c|}
\hline & Charac & teristic score & Score \\
\hline Age $<49$ & & 0 & \\
\hline$>49$ & & 1 & 20 \\
\hline Volume $<$ & $68 \mathrm{~cm} 3$ & 0 & \\
\hline & $68 \mathrm{~cm} 3$ & 1 & 19 \\
\hline Angiogram & Negative & 0 & \\
\hline & Positive & 1 & 18 \\
\hline Spicule & Negative & 0 & \\
\hline & Positive & 1 & 24 \\
\hline Lymph node & Negative & 0 & \\
\hline & Positive & 1 & 17 \\
\hline $\mathrm{HU}$ & & 0 & \\
\hline$>2$ & & 1 & 10 \\
\hline Total score & & & 108 \\
\hline
\end{tabular}

The cross point was determined using Receiver-OperatingCharacteristic (ROC) analysis, that is an analysis using the validity value (sensitivity and specificity) as the standard for determining cross point. Conclusion was made using this analysis, in which the cross point $>35$ has the validity value of $94.6 \%$. In predicting cancer at the cross point $>35$, having the sensitivity $97.7 \%$ and specitivity $83.3 \%$. The cross point was determined considering the sensitivity and specificity values that were optimal in predicting lung cancer.

\section{DISCUSSION}

In approximately $10-20 \%$ of lung cancer cases, the histological type cannot be confirmed because all nonsurgical modalities failed to obtain enough specimens for pathological examinations 4. Unless surgery was performed, these unconfirmed cases cannot be treated properly as lung cancer. Therefore a noninvasive system which is as accurate as pathological examinations is needed for such cases.

This study has proved that HRCT can be used to differentiate malignant tumors from benign lesions in a suspected lung cancer case. Main abnormalities and additional disorders indicated in the CT scan show concording results with the histopathology by about $65-79 \%$. The $78 \%$ of lung cancer patients confirmed through histopathology came from a demographic age group of 49 years and above.

The problem is, not all of the main abnormalities as well as additional lesions are present in each case, therefore a scoring system is necessary to convert the abnormalities into numbers that can be calculated to indicate malignancy or benignity. This study succeeded to develop method that converts the main abnormalities and additional lesions by HRCT plus demographic factor (age) into scores that can be used to differentiate malignancy from non malignancies.

The results of HRCT in 10 patients were benign and this is in accordance with the pathological results. According to analyses all of the 10 patients had total scores of less than 35 which meant that the results of HRCT agreed with the pathological result. Only 1 patient (case 47) with benign results by HRCT with a total score of 30 (benign) showed malignant cells. For benign lesions, the scoring system by HRCT is accordance with pathological results in $90.9 \%$ of cases (10 out off 11 patients).

For the rest of the cases (44 patients) the HRCT score was $\geq 35$. As many as 42 patients $(95,5 \%)$ had pathological results that were in accordance with the HRCT scores. Only 2 patients (case no.1 and 15) showed disagreement between HRCT (total score 38 \& 39, respectively) and pathological results (malignancy cells not found).

Patients with thymoma were included in this study because from chest $\mathrm{x}$-ray, the origin of mediastinal and hilar masses were difficult to determine, whether the tumor arose from the mediastinum or the lung. Until then result of pathology showed thymoma which is mediastinal tumor. Scoring with HRCT to differ malignant and benign tumor can also be used for mediastinal tumor.

Assessing from the HRCT and pathological results, sensitivity was $97.7 \%$, specificity was $83.3 \%$, positive predictive value was $95.5 \%$ and negative predictive value was $90.9 \%$. This means that HRCT can detect $97.7 \%$ of malignant tumors and $90.9 \%$ of benign tumors. The results of HRCT compared to pathology has $94.6 \%$ respectively. This is different from Takanashi et al10 who studied 60 patients with $<2 \mathrm{~cm}$ nodule with HRCT and pathological examinations, in which sensitivity was $56 \%$ and $93 \%$. The difference of sensitivity and specificity in our study was caused by the large tumor size, $68 \mathrm{~cm} 3$, whereas in the Takanashi study tumor size was $<2 \mathrm{~cm}$, meaning cell volume was only $8 \mathrm{~cm} 3$. In their study all of the patients were operated on so that they can have histopathological results. In this study only one patient underwent surgery, the other 54 patients were treated with cytology.

Inconclusion, A new non-invasive method to diagnose lung cancer accurately, with results almost as accurate as histopathological findings, was achieved through the HRCT scoring system. This system has a sensitivity of $97.7 \%$ and specificity of $83.3 \%$ with the cut off score of $>35$ for malignant and $<35$ for benign lesion. 
A

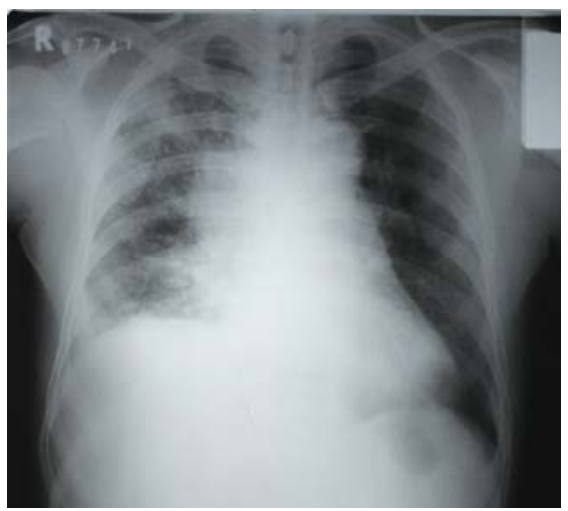

$\mathbf{C}$

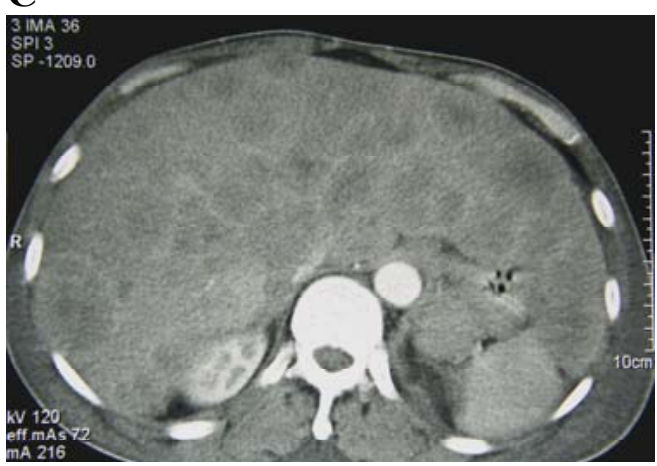

B

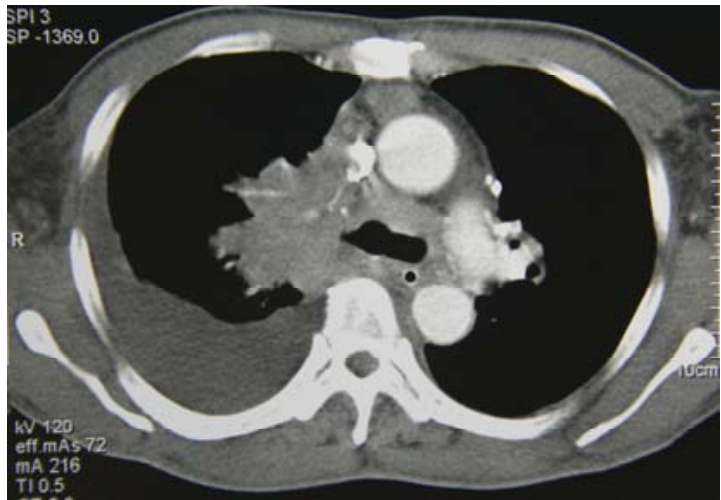

D

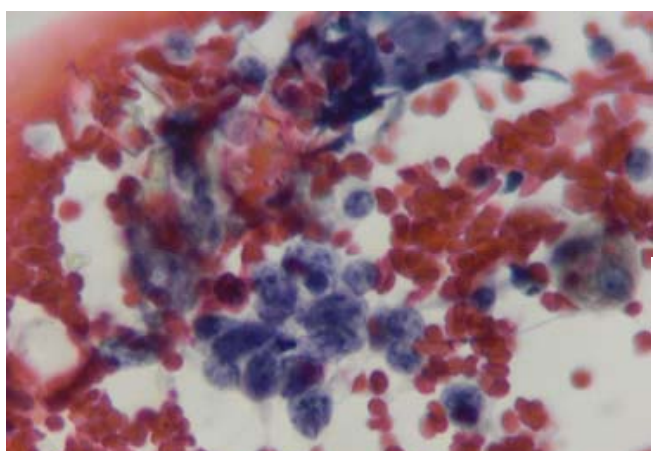

Figure 1. Chest X-ray and CT scan of a patient 56 years old (case 4) with total score 108 and histopathologic small cell carcinoma

A. Chest X Ray, mass in the right hilus with irregular border. Blunt right sinus, Cor enlargement

B. CT, mass with irregular border, volume $185 \mathrm{~cm} 3=$ score 20 , spicula $+=$ score 24 , different $\mathrm{HU} 42=$ score 10 , angiogram $+=$ score 18 , right pleural effusion

C. Metastasses in right and left lobe, Age $56=$ score 20, total score 108 (malignancy)

D. PA Result: Small cell carcinoma, Small cell tumor, pleomorphic nucleus, rough chromatin, irreguler nuclear membrane.

A.

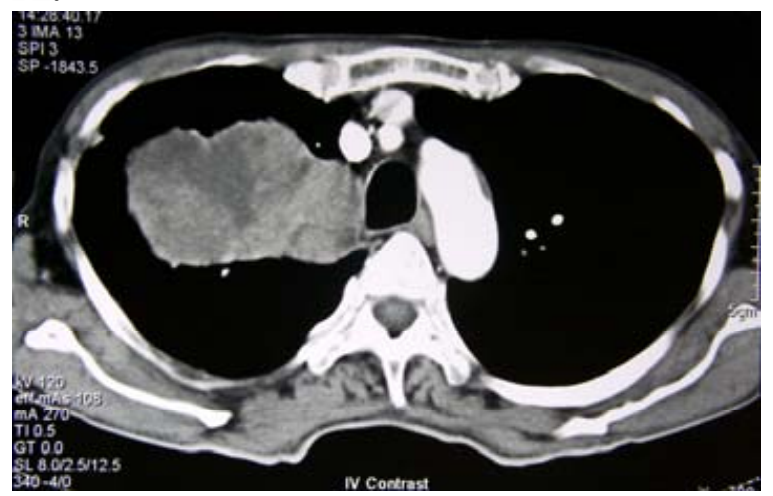

B

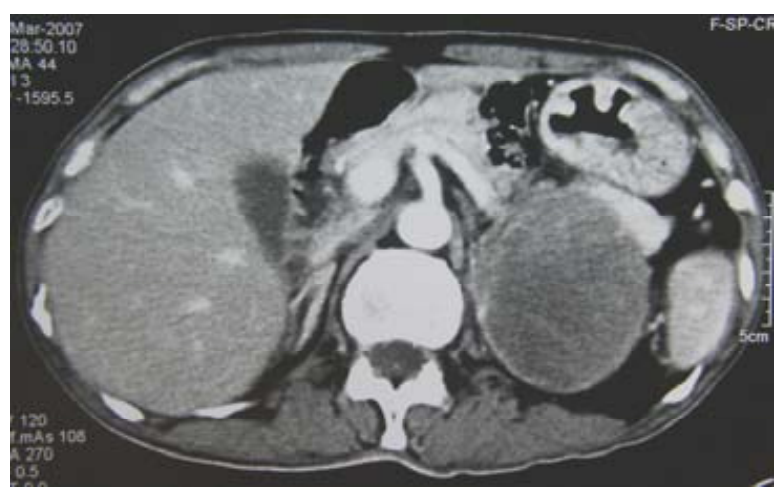

Figure 2. CT scan of 61 years old patient (case 50) with total score 108 and histopathologic squamous cell carcinoma

A. Lobulated tumor, volume $269 \mathrm{~cm} 3=$ score 19 , spicula $+=$ score 24 , different HU $26=$ score 0 , angiogram $+=$ score 18 , lymph node $+=$ score 17 , age $61=$ score 20 . Total score 108

B. Metastasis to left adrenal gland. PA : Squamous cell carcinoma 
A

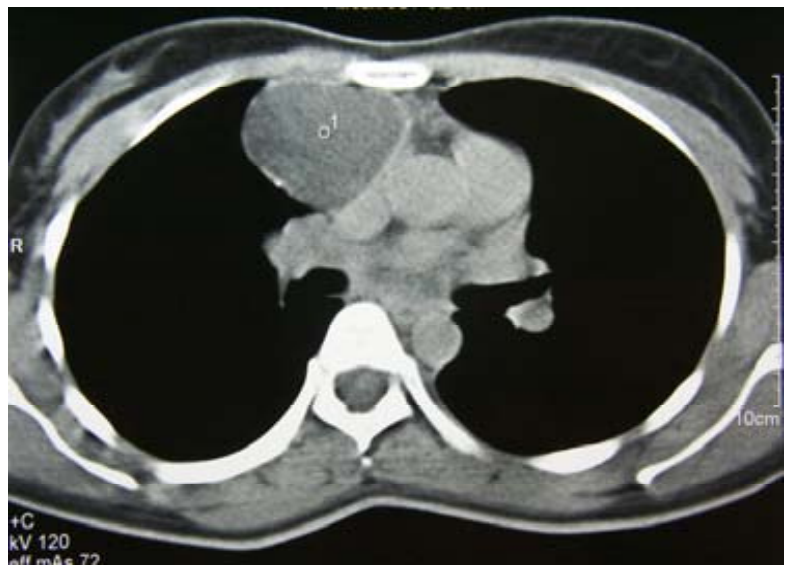

B

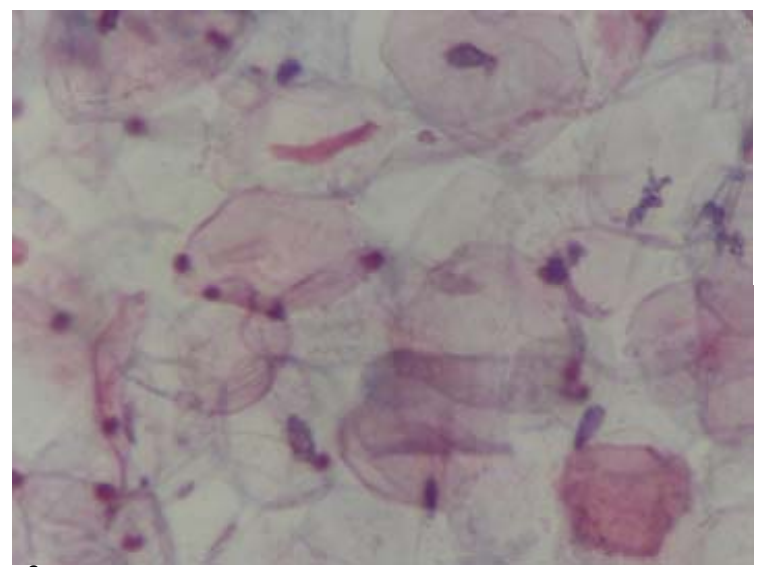

Figure 3. CT scan and histopathologic examination of a 23 years old patient (case 25) with total score 19 and histopathologic teratoma

A. Right mediastinal tumor, volume $132 \mathrm{~cm} 3=$ score 19 , calcification + , different HU 0, spicula - , angiogram - and enlargment lymph node - , age $23=$ score 0 .

Total score 19 (benign).

B. PA of teratoma: squamous epithelium with picnotic nucleus, widening eosinophylic cytoplasm

A.

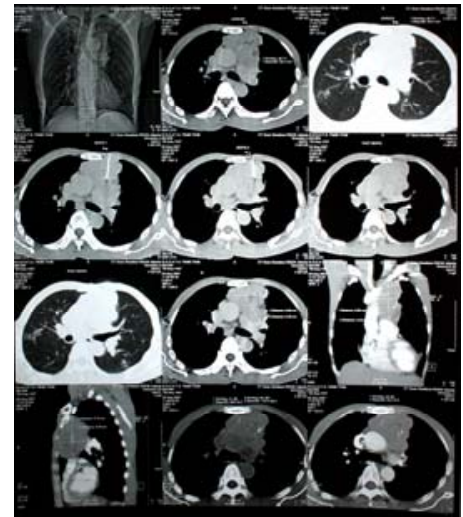

C.

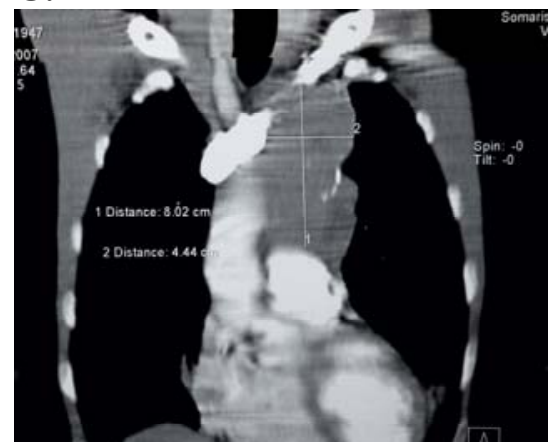

B.

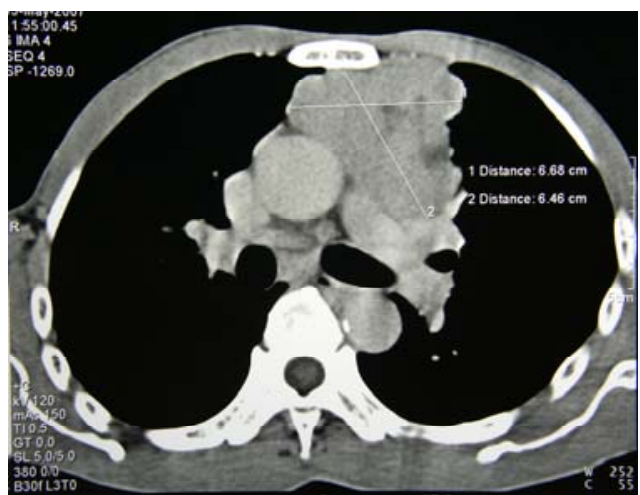

D.

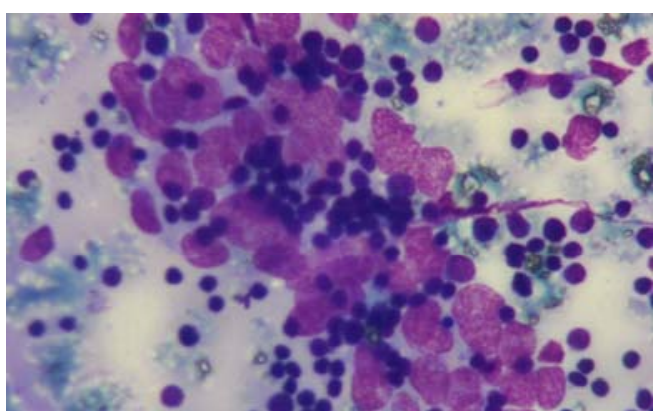

Figure 4. CT scan and histopathologic of a 60 years old patient (case 11) with timoma total score 63

A. Superior mediastinal tumor with TTB, volume $120 \mathrm{~cm} 3=$ score 19 , spicula $+=$ score 24 , different HU 10 , score 0 . age $60=$ score 20. Total score 63 (malignancy)

B. Diameter : lateral - lateral $\mathrm{x}$ anterior - posterior.

C. Diameter : cranio - caudal

D. PA of Thymoma: epithelial cells between lymphocites 


\section{REFERENCES}

1. Alberts Michael W. Lung cancer Guidelines, Chest. 2003; 123:1S-2S

2. Fraser RS, Colman N, Muller NL, Pare PD, Synopsis of disease of the chest 3rd ed. Philadelphia: Elsevier Saunder; 2005.p.348-50.

3 Schrump DS, Altorki NK, Henschke CL, Carter D, Turrisi AT, Guterrez ME. Cancer principles \& practice of oncology.7th ed. Philadelphia, JB Lippincott; 2005; 753-810.

4 Yusuf A.Diagnosis dan penderajatan dalam buku Pidato pengukuhansebagai gurubesartetap dalambidang pulmonologi dan ilmu kedokteran respirasi, pada FKUI 2004.

5. Amin Z. Kanker Paru. In. Sudoyo AW, Setyohadi B, Alwi I, Simadibrata M, Setiati S (editors). Buku Ajar Ilmu Penyakit Dalam. $4^{\text {th }}$ ed. Jakarta: Balai Penerbit Fakultas Kedokteran Indonesia; 2006.p.1019-20

6. Webb R. Lung cancer and bronchopulmonary neoplasma. Thoracic imaging pulmonary and cardiovascular radiology. Philadelphia: JB Lippincott, 2005.p.66-111.
7. Takashima S, Sone S.Li F, Maruyama Y, Hasegawa M, Matsushita T, Takayama F,Kadoya; Small solitary pulmonary nodules $(<1 \mathrm{~cm})$ detected at population based CT screening for lung cancer : Reliable high resolution CT features of benign lesions. AJR 2003;180:955-64.

8. Schaefer-Prokop, M Prokop. Lung and Tracheobronchial system in spiral and multislice computed tomography of the body. Thieme. 2003; 279-372

9. Hyodo T, Kanazawa S, Dendo S, Kobayashi K, Hayashi H, Kouno Y. Intrapulmonary lymph nodes: Thin-section CT findings, pathological findings, and CT differential diagnosis from pulmonary metastatic nodules. Acta Med. Okayama, 2004; 58,No 5, pp.235-40

10. Takanashi N, Nobe Y, Asoh H,Yano T, Ichinose Y. The diagnostic accuracy of a solitary pulmonary nodule, using thin section high resolution CT: A solitary pulmonary nodule by HRCT. Lung Cancer 13 (1995);105-12. 